\title{
Infecção pós-artoplastia total do joelho - Considerações e protocolo de tratamento
}

\author{
Infection following total knee joint arthroplasty: considerartions and treatment
}

\begin{abstract}
Ana Lúcia lei Munhoz Lima', José Ricardo Pécora², Roberto Motta Albuquerque ${ }^{2}$. Adriana Pereira de Paula ${ }^{3}$, Caio Olineira D'Elia4, Alexandre Leme Godoy dos Santos ${ }^{4}$, Alberto Tesconi Croci ${ }^{5}$.
\end{abstract}

\section{RESUMO}

As artroplastias totais de joelho apresentaram nas últimas décadas apreciável melhora em relação aos resultados cirúrgicos devido à difusão de técnicas operatórias precisas e ao desenvolvimento de materiais de implante de alta tecnologia. Apesar disso ainda estão sujeitas a complicações, sendo a infecção a mais difícil de ser solucionada.

Neste artigo discutimos os fatores de risco para infecção, classificação, condições clínicas e cirúrgicas, assim como métodos diagnósticos. As opções de tratamento incluem supressão com antibióticos, manutenção da prótese, troca imediata ou em dois tempos dos componentes protéticos e os procedimentos de salvação. Além disto, os autores apresentam o protocolo de tratamento utilizado no Instituto de Ortopedia e Traumatologia do Hospital das Clínicas da FMUSP pelo Grupo de Artroplastias.

Descritores: Artroplastia do Joelho; Infecção, Fatores de risco.

\section{INTRODUÇÃO}

O conceito de substituição da superfície articular do joelho, para o tratamento de doenças graves dessa articulação, tem recebido atenção desde o século XIX. Já em 1860, Verneuil(15) sugeriu a interposição de partes moles para a reconstrução articular do joelho. Mas foi no início do século passado que a artroplastia total de joelho (ATJ) apresentou grande evolução, devido ao desenvolvimento de materiais de implante adequados para a interposição articular - como ligas metálicas e acrílico -, e ao aprimoramento da técnica cirúrgica, alavancado principalmente por Campbell(1), Maclntosh ${ }^{(10)}$ e McKeever ${ }^{(11)}$.

Atualmente, existem à disposição próteses de joelho com desenhos e materiais de alta tecnologia, que, aliado ao aumento da expectativa de vida da população mundial e ao diagnóstico mais preciso das doenças ortopédicas, fez aumentar sensivelmente a indicação e a sobrevida das mesmas.

\section{SUMMARY}

Total knee arthroplasty results have markedly improved during the last decades due to diffusion of accurate surgical techniques and development of high-technology implant materials. However, complications still develop, infection being that of most difficult resolution.

Risk factors for infection, classification of infections, clinical and surgical conditions, as well as diagnostic methods are discussed in the present article. Therapeutic options include suppression by antibiotic therapy, maintenance of the prosthesis, immediate or twostep replacement of prosthetic, and salvage procedures. In addition, the authors describe the treatment protocol used by the Arthroplasty Group in the Institute of Orthopedics and Traumatology (I.O.T.) of the Clinics Hospital of the Medical School of the São Paulo University.

Keywords: Arthroplasty,Replacement, Knee; Infection, Risk Factors

\section{INTRODUCTION}

The conception of replacement of the knee joint surface as a treatment for severe knee joint diseases has drawn the attention since the XIX century. In 1860 Verneuil(15) suggested the insertion of soft tissue for knee joint reconstruction. However, at the beginning of the past century the knee joint arthroplasty (KJA) greatly developed due to the development of adequate implant materials, such as metallic and acrylic alloys, and the improvement of the surgical technique, mainly stimulated by Campbel/(1), Maclntosh $^{(10)}$ e McKeever ${ }^{(11)}$

There are high-technology knee prostheses of different designs available today. With increased life expectancy worldwide and more accurate diagnoses, the use of such prostheses has led to increased indication and survival.

The main objectives of knee joint arthroplasty are pain relief, functional gain achievement, and deformity repair. It is mainly in-

Work performed at the Orthopedics and Traumatology Department of the University of Sao Paulo School of Medicine.

1 - Communicable Disease Specialist, Chief of Infection Service of the IOT-FMUSP 2 - Orthopaedist, Assistant physician of the Arthroplasty Group IOT-FMUSP

3 - Nurse of the Commission of Hospital Infection Control of IOT-FMUSP

4 - Resident physicians IOT-FMUSP

5 - Full Professor, Chief of the Arthroplasty Group IOT-FMUSP 
As finalidades básicas deste procedimento são aliviar a dor, obter ganho funcional e corrigir deformidades, sendo indicado basicamente nas osteoartroses, doenças reumáticas, hematológicas e osteonecroses ${ }^{(6)}$.

A ATJ consiste basicamente na substituição da articulação, em seus segmentos femoral, tibial e patelar por implantes protéticos, constituídos por um componente femoral de metal, um componente tibial com base metálica que suporta uma base de polietileno, e o componente patelar formado somente por polietileno.

É considerada uma cirurgia de grande porte, passível de uma série de complicações pós-operatórias, sendo a infecção uma das piores e mais temidas, representando verdadeiro desafio ao cirurgião ortopédico, por ser de tratamento difícil e prolongado(6).

\section{Incidência:}

Não há estatística nacional de infecção em ATJ.

$\mathrm{Na}$ literatura internacional a incidência é de 1\% a 5\%. Nos centros de excelência, com equipe especializada e grande volume de ATJ, esse índice pode chegar a menos de 1\%.

O impacto econômico do tratamento das ATJ infectadas chega a trezentos milhões de dólares anualmente nos Estados Unidos ${ }^{(13)}$.

No Instituto de Ortopedia e Traumatologia ( I.O.T. ) da Faculdade de Medicina da Universidade de São Paulo, a incidência de infecção nas ATJ tem se mantido ao redor de $3 \%{ }^{(9)}$.

\section{Etiologia:}

As infecções pós ATJ apresentam três vias de ocorrência, a saber por implantação direta de bactérias, via hematogênica ou pação de focos quiescentes.

A implantação direta no ato operatório, é devida ao ambiente cirúrgico inadequado, a falha na técnica de esterilização e ao tempo cirúrgico prolongado.

A contaminação por via hematogênica geralmente ocorre a partir da disseminação de foco à distância como infecção do trato urinário ou pulmonar, úlcera de pele infectada e abscessos odontogênicos.

Outra via de infecção é a reativação de foco quiescente osteoarticular como pioartrites, osteomielites ou manipulações cirúrgicas prévias

Os microrganismos causadores das infecções articulares pós ATJ incluem: bactérias gram positivas em 50 a $60 \%$ dos casos, bactérias gram negativas em 10 a 20\%, e mista em 10 a 20\%, em sua maioria aeróbias ${ }^{(4)}$.

As bactérias que apresentam maior prevalência mundial ${ }^{(14)}$ e as mais prevalentes no I.O.T. ${ }^{(8)}$, estão representadas no Quadro 1 e 2 respectivamente.

Os microrganismos patogênicos menos freqüentes são: fungos, principalmente Candida sp, e o bacilo da Tuberculose. dicated in osteoarthroses, rheumatic and hematologic diseases, and osteonecroses ${ }^{(6)}$.

KJA consists of joint replacement in their femoral, tibial, and patellar segments with prosthetic implants, made of a metal femoral component, a tibial component made of a metallic base supporting a polyethylene base, and a patellar component made of polyethylene only.

KJA is a great surgery and several postoperative complications may develop, including infection, the most severe and feared complication. Infection in KJA is a challenge because treatment is difficult and often time-consuming(6).

\section{Incidence}

National data of KJA infection are not available.

International literature reports an incidence of 1\%-5\%. In excellence centers with specialized staff and great volume of KJA, this rate amounts to less than $1 \%$.

Economic impact of infected KJA treatment amounts to US\$ 300 million per year in the United States ${ }^{(13)}$

In the Institute of Orthopedics and Traumatology (I.O.T.) of the Medical School of the São Paulo University, the incidence of KJA infection has been stable for the last three years, amounting to approximately $3 \%{ }^{(9)}$.

\section{Etiology}

Post-TKA infections can develop through three mechanisms: direct implant of bacteria; hematogenic route; reactivation of quiescent foci.

Direct implant during surgery results from an inadequate surgical environment, faulty sterilization technique, and prolonged surgical duration.

Hematogenic contamination generally stems from distant foci, such as urinary tract or pulmonary infections, infected skin ulcers, and odontogenic abscesses.

Another infection route is the reactivation of osteoarticular quiescent foci, such as pyoarthritides, osteomyelitis, or previous surgical manipulations.

Microorganisms causing joint infections following total knee joint arthroplasty include Gram-positive bacteria in 50\% to 60\% of cases, Gram-negative bacteria in $10 \%$ to $20 \%$, and mixed in $10 \%$ to $20 \%$. In most cases, aerobic bacteria are involved(4).

Tables 1 and 2 show the most prevalent bacteria worldwide ${ }^{(14)}$ and in the I.O.T. ${ }^{(8)}$, respectively.

Less frequent pathogenic microorganisms include fungi, mainly Candida sp, and the tuberculosis bacillus.

\section{Risk Factors for Infection}

The risk for infection in KJA is related to host's condition, surgical environment, and the surgical intervention itself.

As for the host, some systemic diseases, lifestyle, and clinical conditions (Table 3) contribute to increasing the risk for infection in KJA. 


\section{Fatores de risco para infecção \\ O risco de infecção na} ATJ está relacionada à condição do hospedeiro, do ambiente cirúrgico e da cirurgia propriamente dita.

Em relação ao hospedeiro, algumas doenças sistêmicas, hábitos de vida e condições clínicas (Quadro 3) contribuem para aumentar o risco de infecção nas ATJs.

Quanto ao ambiente cirúrgico é de vital importância, na prevenção da infecção pós-artroplastia, a manutenção do sistema de ar condicionado, utilização de fluxo de ar laminar, esterilização e acondicionamento adequado dos materiais protéticos, bem como a técnica de anti-sepsia e paramentação correta da equipe cirúrgica e do campo operatório

A cirurgia, propriamente dita, contribui para aumentar o risco de infecção quando realizada com técnica inadequada, com tempo cirúrgico prolongado, manipulação excessiva de partes moles e número elevado de pessoas no campo operatório

\section{Diagnóstico:}

A dor é um sintoma importante, quase universalmente encontrado nas artroplastias de joelho infectadas.

No exame clínico do joelho podemos observar aumento de volume, calor, edema, derrame articular, hiperemia, fístula e necrose cutânea. A amplitude de movimento pode estar diminuída.

A estabilidade da articulação e o exame neurovascular do membro inferior geralmente não são afetados.

A progressão na reabilitação mostra-se claramente alterada.

Os exames sanguíneos que auxiliam na investigação são: a contagem de leucócitos e seu diferencial, velocidade de hemossedimentação, dosagem de proteína-C reativa e alfa 1-glicoproteína ácida. Apesar de não específicos, quando alterados, corroboram para o diagnóstico de infecção.

Para prosseguir a investigação diagnóstica, pode ser realizada a punção aspirativa da articulação, com obtenção de lí-
As for surgical environment, measures are of paramount importance to prevent infections following KJA, such as maintenance of the air-conditioning system, use of laminar airflow, sterilization, and appropriate prosthetic material packaging, as well as antisepsis technique, appropriate use of drapes, and appropriate adornment of the surgical staff.

The surgical procedure itself contributes to increasing the risk for infection, when the technique is inappropriate, surgical duration is long, manipulation of soft tissue is excessive, and there is a great number of persons in the operative field.

\section{Diagnosis:}

Pain is an important symptom and found in almost all patients with infection following KJA.

Clinical examination of the knee may show increased volume, increased local temperature, edema, joint effusion, hyperemia, fistula, and skin necrosis. Movement range may be decreased.

Joint stability and neurovascular examination of the legs are not affected in most patients.

Rehabilitation course is clearly presened.

Blood tests useful for diagnosis include white blood cell count (including differential count) erythrocyte rate sedimentation, C-reactive protein, and acid a-glycoprotein. Although these tests are not specific, abnormal results corroborate the diagnosis of infection.

Fluid aspiration allows one to obtain synovial fluid to confirm diagnosis. Gram staining and culture for aerobic and anaerobic bacteria are used to evaluate synovi) 112 fluid and has high rates of sensitivity, specificity, and accuracy ${ }^{(12)}$.

In some cases where infection is presumed and diagnosis is not confirmed, arthroscopic biopsy of synovial tissue is indicated for histopathological and bacteriological analysis ${ }^{(7)}$.

As for imaging testing, plain radiographs can show prosthesis release and bone involvement while ultrasonography can demonstrate periarticular or intraarticular collection. When clinical picture and joint aspiration are not conclusive, scanning with te- 
quido sinovial para exame de coloração pelo método de Gram e cultura para bactérias aeróbias e anaeróbias. Este exame apresenta altos índices de sensibilidade, especificidade, e acurá$\mathrm{cia}^{(12)}$.

Em alguns casos, com suspeita de infecção, mas sem diagnóstico estabelecido, indica-se biópsia artroscópica do tecido sinovial para análise histopatológica e bacteriológica ${ }^{(7)}$.

Em relação aos exames de imagem, o RX simples pode evidenciar soltura da prótese e acometimento ósseo, já a ultrassonografia pode detectar coleção peri ou intra-articular. Quando o quadro clínico e o exame de punção articular são inconclusivos, o mapeamento com leucócitos marcados com tecnécio pode ser definitivo por ter alta sensibilidade e especificidade para as infecções osteoarticulares.

O protocolo preconizado pelos autores, para investigação diagnóstica de ATJ infectadas inclui: história e exame físico padronizados, leucograma, velocidade de hemossedimentação, proteína C reativa, alfa 1-glicoproteína ácida, punção articular e radiografias simples de joelho nas incidências antero-posterior e perfil. Esta investigação é complementada por cintilografia com leucócitos marcados e biópsia artroscópica de tecido sinovial nos casos duvidosos.

\section{Classificação:}

O Center for Diseases Control and Prevention U.S.A.(C.D.C.) classifica as infecções pós artroplastia total de joelho de acordo com a localização, em superficiais e profundas e quanto ao tempo de infecção, em agudas e crônicas ${ }^{(2)}$.

As infecções superficiais são aquelas que acometem as partes moles acima da fáscia muscular, e portanto são extra-articulares.

Infecções profundas ocorrem quando o microrganismo está intra-articular.

Quando o diagnóstico é feito até quatro semanas de pósoperatório, a infecção é classificada como aguda. A infecção é dita crônica quando o tempo decorrido entre a cirurgia e o diagnóstico for maior que o período citado.

\section{Tratamento:}

As alternativas de tratamento são apresentadas no Quadro 4.

Manutenção da prótese: são duas as formas de tratamento que procuram não retirar a prótese:

Antibioticoterapia específica de supressão guiada pelo resultado da cultura e antibiograma obtidos por punção aspirativa, apresentando resultados com baixos índices de sucesso(4).

Desbridamento cirúrgico com troca do polietileno do componente tibial da prótese, é o método preconizado pelos autores para casos bem selecionados. Está indicado em infecções chnetium-labelled white blood cells can be definitive since it has high sensitivity and specificity for osteoarticular infections.

The authors recommend the following protocol for diagnosis of infection following KJA: history and physical examination, white blood cell count, erythrocyte sedimentation rate, C-reactive protein, and acid a-glycoprotein, joint aspiration, and plain radiographs of the knee joint (anteroposterior and lateral incidences). In addition, scintigraphy with Tc-labelled white blood cells and arthroscopic biopsy of synovial tissue may be carried out in difficult cases.

\section{Classification:}

The Center for Diseases Control and Prevention - U.S.A.(C.D.C.) classifies infections following total knee joint arthroplasty according to their localization (superficial or deep) and duration (acute and chronic) (2)

Superficial infections are those affecting soft tissues over muscular fascia, being therefore extraarticular.

Deep infections develop when intraarticular microorganisms are found.

Acute infection is defined as that diagnosed within 4 weeks following KJA while chronic infection is defined as that diagnosed beyond 4 weeks following KJA.

\section{Treatment:}

Therapeutic options are shown in Table 4.

Prosthesis Maintenance: two therapy options are available when the prosthesis is to be maintained:

Specific suppression antibiotic therapy, defined according to results of culture and antibiotic sensitivity testing of synovial fluid specimens obtained by aspiration, with low rates of success $^{(4)}$.

\begin{tabular}{lll}
\hline Manutenção da prótese/ & Troca da prótese/ & Salvamento \\
Prosthesis Maintenance & Prosthesis Replacement & Salvage \\
\hline Antibioticoterapia de supressão & Tempo único & Artrodese \\
Suppression antibiotic therapy & One-step & Arthrodesis \\
\hline Desbridamento cirúrgico/ & Dois tempos & Artroplastia de \\
Surgical debridement & Two-steps & $\begin{array}{l}\text { ressecção } \\
\end{array}$ \\
& & Resection \\
& & arthroplasty \\
\hline & & Amputação \\
& & Amputation \\
\hline
\end{tabular}

Quadro 4 - Métodos de tratamento para ATJ infectadas

Table 4 - Therapy options of infections following KJA

\section{Surgical debridement with} polyethylene replacement of the tibial component of the prosthesis is indicated by the authors for selected cases. It is indicated in acute infections of less than 2 weeks' duration, always associated with specific antibiotic therapy for six to eight weeks ${ }^{(16)}$.

\section{Prosthesis Replacement}

Immediate replacement: in this case, the patient is submitted to meticulous and extensive surgical debridement with extended synovectomy. All necrotic tissue that is not apparently viable is removed. All prosthesis components are then replaced and orthopedic cement impregnated with antibiotic is used between prosthesis interfaces and bones. 
agudas com menos de duas semanas de evolução, sempre associado à antibioticoterapia sistêmica específica durante seis a oito semanas ${ }^{(16)}$

\section{Troca da Prótese}

Troca imediata: nessa modalidade de tratamento o paciente é submetido a desbridamento cirúrgico minucioso e extenso, com ampla sinovectomia retiradando-se todos tecidos necróticos aparentemente inviáveis. Em seguida, no mesmo ato cirúrgico, trocase todos os componentes da prótese, sendo utilizado cimento ortopédico impregnado por antibiótico na interface dos componentes protéticos com o osso.

Na intervenção cirúrgica é colhido material para realização de cultura e antibiograma, objetivando a instituição de antibioticoterapia específica e dirigida. Este tipo de protocolo tem se mostrado efetivo no tratamento das infecções com vantagens relacionadas a um período de internação mais curto e um resultado funcional melhor, visto que, o paciente tratado desta forma pode mais rapidamente retornar à reabilitação(3).

Troca em dois tempos: considerado tratamento de escolha por muitas escolas e preferido pelos autores. O paciente é submetido a desbridamento cirúrgico com a retirada de todos os componentes da prótese. Um espaçador de cimento ortopédico impregnado com antibiótico de largo espectro é interposto na articulação. O antibiótico a ser adicionado ao cimento pode ser escolhido de acordo com as bactérias mais prevalentes nestas infecções, levando-se em consideração suas características farmacocinéticas

A participação do espaçador de cimento com antibiótico no combate da infecção está relacionado com a liberação local de antibiótico e com a ocupação de espaço morto intra-articular. Isto previne a formação de hematoma, que é ambiente favorável à proliferação e perpetuação de infecção.

Este espaçador tem também o objetivo de prevenir a retração de partes moles facilitando a colocação de prótese definitiva e no protocolo dos autores é modelado com componente femoral e tibial o que permite a flexo-extensão do joelho, colaborando para um melhor resultado funcional final. É mantido na articulação por 6 a 8 semanas, associado a antibioticoterapia sistêmica dirigida para o agente isolado em cultura.

Ao término da primeira fase do tratamento, se não houver indícios clínicos e laboratoriais de infecção, o paciente é submetido a punção articular e a biópsia articular artroscópica para coleta de material para cultura e antibiograma. Quando negativas, autorizam a colocação da prótese de revisão definitiva, associada a continuidade da antibioticoterapia por seis meses nos casos de infecção crônica ${ }^{(5)}$.

Caso a punção articular ou a biópsia artroscópica apresentem-se positivas, é indicado novo desbridamento cirúrgico com troca do espaçador de cimento impregnado com antibiótico e manutenção da antibioticoterapia sistêmica. Após seis semanas é realizada nova punção e biópsia por via artroscópica para reavaliação do controle da infecção.

\section{Procedimentos de Salvamento}

O sucesso no tratamento da infecção em uma ATJ infectada não é obtido em todos o casos. Em pacientes imunocomprometidos, ou naqueles que pelo retardo de tratamento da infecção apresentam importante comprometimento de partes moles ou ósseas, torna-se proibitiva qualquer tentativa de ma-
During surgery tissue specimens are collected for culture and antibiotic sensitivity testing; results of these tests are important to define targeted and specific antibiotic therapy. This type of protocol has been shown to be effective in the treatment of infections with advantages associated with shorter hospitalization stays and better functional results since patients submitted to this type of treatment can be referred to rehabilitation within a shorter time ${ }^{(3)}$.

Two-step replacement: it is considered the treatment of choice by many schools and is preferred by the authors. The patient is submitted to surgical debridement with removal of all prosthesis components. A spacer of orthopedic cement impregnated with a broad-spectrum antibiotic is inserted within the joint. The antibiotic to be added to cement can be selected according to the most prevalent bacteria in this type of infection, taking into account their pharmacokinetic profile.

The role of the spacer with cement impregnated with antibiotic in the fight against infection is associated with local release of antibiotic and occupancy of intraarticular dead space, thus preventing formation of hematomas, a favorable environment for proliferation and perpetuation of infection.

The use of this spacer aims to prevent retraction of soft tissue. Therefore, placement of the definitive prosthesis is made easier. In authors' protocol, it is modeled with the femoral and tibial components. Flexoextension of the knee joint is then possible, which contributes to a better final functional result. It is kept within the joint for 6 to 8 weeks, in association with systemic antibiotic therapy, defined according to culture testing.

After the first phase of treatment is completed and if there is no clinical or laboratory evidence of infection, the patient is submitted to joint aspiration and arthroscopic biopsy for collection of specimens for culture and antibiotic sensitivity testing. When test results are negative, one may consider the placement of the definitive orthesis. Antibiotic therapy must be maintained for six months in cases of chronic infection ${ }^{(5)}$.

In case joint aspiration or arthroscopic biopsy is positive, surgical debridement must be repeated and the spacer with cement impregnated with antibiotic must be replaced. Systemic antibiotic therapy must be maintained. Six weeks following debridement, joint aspiration and arthroscopic biopsy are repeated to reevaluate infection control.

\section{Salvage Procedures}

Treatment for infection following KJA is not successful in all cases. In immunocompromised patients or in those who develop an extensive involvement of soft tissues or bones due to delay in initiating treatment for infection, the prosthesis must not be maintained or replaced. In these cases, salvage procedures are indicated and aim to partially preserve the function of the leg.

Arthrodesis: it is the most widely used procedure of salvage and consists of the bony union of femur and tibia; plates and screws can be used, as well as intramedullary rods or external fixators, as the authors prefer to do.

Resection arthroplasty: no stabilization method is used. Local fibrosis is expected to produce some joint stability. The use of a leg orthosis is needed.

Amputation: used only in dramatic cases where infections threatens patient's life. Surgery is followed by rehabilitation with the use of an orthosis. 
nutenção ou colocação de nova prótese. Nesses casos, algumas formas de tratamento apresentam-se como procedimentos de salvação, representando apenas a preservação parcial da função do membro inferior.

Artrodese: é o procedimento mais utilizado como medida de salvamento, que consiste na fusão óssea do fêmur com a tíbia; sendo que a fixação pode ser realizada com placa e parafusos, com haste intra-medular, ou como preferem os autores com fixadores externos.

Artroplastia de ressecção: nesta forma de tratamento, não se usa nenhum método para estabilizar a articulação esperando-se que a formação de uma fibrose local confira alguma estabilidade articular. É necessário o uso de órtese para o membro inferior.

Amputação: utilizada somente em casos dramáticos, nos quais o quadro infeccioso põe em risco a vida do paciente. Essa cirurgia é seguida de reabilitação com aparelho protético.

\section{CONCLUSÃO}

A busca incessante pela diminuição nos índices de infecção, vem promovendo constante esforço no sentido de estabelecer formas de tratamento que ofereçam uma articulação indolor, estável e com grau de mobilidade aceitável.

Os estudos revisados na literatura mundial, indicam que o protocolo de diagnóstico e tratamento defendido pelos autores apresentam o melhor índice de sucesso; pois demandam menor tempo de tratamento e menor recidiva da infecção, associado a maior preservação funcional da articulação.

Nosso estudo, que visa padronizar essa terapêutica de manipulação das infecções pós artroplastia total de joelho, está em andamento e os achados preliminares corroboram com os resultados da literatura.

\section{CONCLUSION}

Constant efforts have been made in an attempt to reduce infection rates and resulted in the development of treatments offering a painless and stable joint with an acceptable movement range.

The review of worldwide literature shows that the diagnosis and treatment protocol recommended by the authors is associated with the better rate of success since therapy duration is shorter and a lower reinfection rate has been seen, in association with better functional preservation of the joint.

The present study aims to standardize the treatment for infections following total knee joint arthroplasty and is underway. Preliminary results corroborate the results reported in literature.

\section{REFERÊNCIAS BIBLIOGRÁFICAS}

1. Campbell WC. Interposition of vitallium plates in arthroplasties of knee: preliminary report. Am J Surg 47:639, 1940

2. Garner JS. C.D.C. Guideline for prevention of surgical wound infection. Infect. Control, 7:193-200, 1995.

3. Goksan SB, Freeman MA. One-stage reimplantation for infected total knee arthroplasty. J Bone Joint Surg Br 74:780-782,1992.

4. Hansen AD, Rand JA. Evalution and treatment of infection at the site of a total knee arthroplasty. J Bone Joint Surg Am 80:910, 1998.

5. Hirakawa K, Stulberg BN, Wilde AH, Bauer TW, Secic M. Results of 2-stage for infected total knee arthroplasty. J Arthroplasty 13:22-28, 1998.

6. Insall J, Clarke H. Historic, development, classification and characteristics of knee prostheses, In : Insall and Scott. Surgery of the Knee. Vol 2,p1516- 1552. Churchil Livingstone, Third Edition, 2001, USA.

7. Insall J. Infection of total knee arthroplasty. Instr Course Lect 35:319-324, 1986.

8. Lima ALLM. Fatores preditivos de infecção em pacientes com diagnóstico de fratura exposta dos membros inferiores. [Tese]. São Paulo: Faculdade de Medicina da Universidade de São Paulo, 2001.
9. Lima ALLM. Infecções hospitalares em 46 pacientes submetidos a Artroplastia total de quadril. [Dissertação]. São Paulo: Faculdade de Medicina da Universidade de São Paulo, 1995.

10. Maclntosh DL. Hemiarthroplasty of the knee using a space occupying prothesis for painful varus deformities. J Bone Joint Surg Am 40:1431, 1958

11. McKeever DC. Tibial plateau prothesis. Clin Orthop 18:86, 1960

12. Mont MA, Waldman BJ, Hungerford DS. Evaluation of preoperative cultures before second-stage reimplantation of a total knee prothesis complicated by infection. J Bone Joint Surg Am 82:1552-1557, 2000

13. Morrey BF, Westholm F, Schoifet $S$ et al. Long-term results of varius treatment options for infected total knee arthroplasty. Clin Orthop 248:120-128, 1989

14. Poss R, Thornhil TS, Ewald FC et al. Factors influencing the incidecy and outcome of infection following total joint arthroplasty. Clin Orthop 182:117-126, 1984.

15. Verneviul A. De la création d'une fausse articulation par section ou ressection partielle de l'os maxillaire inférieur, comme moyen de rémedier a l'ankylose vraie ou fausse de la machoire inférieure. Arch Gen Med 15:174, 1840.

16. Wasielewski RC, Barden RM, Rosemberg AG. Results of different surgical procedures on total knee arthroplasty infections. J Arthroplasty 11:931-938, 1996 